\title{
War and history: \\ Transformation of the concept due to ascending racial ideology and social Darwinism in the $19^{\text {th }}$ Century
}

\section{Ivo BUDIL}

\author{
Katedra historických věd, Fakulta filozofická, Západočeská univerzita v Plzni \\ Department of Historical Sciences, Faculty of Philosophy and Arts, University of West Bohemia \\ Tylova 18, 30125 Plzeň, Czech Republic \\ budil@khv.zcu.cz
}

The Eurasian revolution taking place approximately from 1750 to 1830 brought radical change to relations between key power centres of Eurasia and essential disruption of global power balance characteristic to the world of early modern age. ${ }^{1}$ While in 1800 , the Europeans had directly dominated 35\% of world dry land; in 1878 it amounted to $67 \%$ and in 1914, to more than $84 \% .^{2}$ The Ottoman Empire, India of Great Mughals and China were not able to face the mighty growth of Western economic, military, political and symbolical power caused by industrial revolution and other socio-economic changes in life of the European society at the turn of the $18^{\text {th }}$ and $19^{\text {th }}$ Centuries. Japan was able, thanks to its isolationist policy and internal socio-cultural consistency, to stand up to Western assertiveness and in the Meiji period, after 1868, re-find a relatively dignified place within the new world system with core in Western Europe and North America. Different was the situation of the Ottoman Empire after conclusion of peace treaty with Russia in Küçük Kaynarca on 21 July 1774, of India after the Battle of Plassey fought on 23 June 1757 or of Persia after confirmation of Turkmanchai Treaty from 22 February 1828. The Chinese resistance was defeated in the Opium War in 1839 to 1842, the last echo of the Eurasian revolution. After the disintegration of the Spanish overseas empire, the countries of Central and South America did not produce sufficient dynamism to meet the demands of modernism, succumbed to stagnation and political chaos and transformed into a large dependent peripheral zone. Africa and Pacific islands became the "Heart of Darkness", "Barbarian Zone", passively waiting for external actors to deplete their natural and human resources.

The system of racial hierarchy, as developed in Western visions in the first decades of the $19^{\text {th }}$ Century, represented the global metaphor of world, originated by the Eurasian revolution. The striking irregularity of world economic development, wealth in prideful towns of Anglo-Saxons, stagnation in trade centres of the Mediterranean, the Orient and Latin America and the prehistoric underdevelopment in the interior of Africa constituted, similarly to the results of war conflicts, a strong argument in favour of essential differences in racial predispositions, advantages of racial purity and harmfulness of racial mixing. Race became a privileged tool of cognition and understanding of dramatic changes taking place in the

1 John DARWIN, After Tamerlane: The Global History of Empire since 1405, London 2007, 160.

2 Paul KENNEDY, Vzestup a pád velmocí: Ekonomické proměny a vojenské konflikty v letech 1500 až 2000, Praha 1996, 191. 
world at the beginning of modern age.

Racial classification of humanity was gradually asserted due to the development of Western natural sciences during late decades of the $18^{\text {th }}$ Century when more and more intellectuals, inspired by François Bernier and Johann Friedrich Blumenbach, emphasized the historical importance of somatic diversity of mankind. The mobilization of popular masses in the course of the French Revolution and Napoleonic Wars ignited collective emotions manifested through metaphors of blood, violence and patriotism. Race became the optimal concept to capture and shield that new semantic field. The authority of natural sciences and the spirit of Enlightenment and secularization supported transfer of biological metaphors to social and historical sciences. The category of race was strengthened also due to the retreat of traditional environmentalism. More and more Western thinkers believed that inborn and hereditary somatic features had more important impact on fates of human societies than climatic and geographical factors. For example Constantin François Volney, a French Orientalist, reassessed shortly before the French Revolution the traditional Hippocratic environmentalism and called physiognomy, an important evidence of the past of a relevant population: The nations of Europe and Asia had their history recorded in their faces. ${ }^{3}$ Modern racial theory was developed in an atmosphere of intellectual harmony among natural scientists like William Frédérick Edwards and historians like Augustin and Amédée Thierry or Jules Michelet or economist Charles Dunoyer. Henry Maine mentioned that the discovery of Sanskrit and Indian studies had serious political consequences: A new theory of language gave rise to a new theory of race. Populations among whose languages could similarities to be found started emphasizing their historical relationship from which political bonds were derived. As Henry Maine wrote, the fact that people who do not understand each other can be politically associated based on a suspected linguistic bond constituted a completely new idea. The idea led to Pan-Germanism, Pan-Slavism and Pan-Celtism. ${ }^{4}$

After 1848, when the liberal expectations related to European revolutionary disorders had not been fulfilled, biological understanding of race as fatal predicate justifying historically privileged status of specific population was asserted. While Montesquieu had viewed Germanism, nostalgic revival of Tacitean idealization of ancient Germans as defence of human liberty, Arthur Gobineau in the 1850s considered Germanship a racial disposition conditioning civilization vitality, strength and superiority. The racial dichotomy between the Aryan and Semitic element, popularized mainly by Benjamin Disraeli and Ernest Renan, brought a seed of inner conflict into the Western society.

The understanding of history as ethnic or racial rivalry had had long tradition particularly in France, in connection with the memories of "migration of peoples" and German expansion that had founded the political order of early Middle Ages to considerable extent. For example in early $18^{\text {th }}$ Century, Count Henri de Boulainvilliers highlighted the fatal ethnic fight between autochthonous Gallic Romans and alochthonous German Franks. ${ }^{5}$ Shortly before the Fall of the Bastille, Abbé Emmanuel Joseph Sieyès appealed with impassioned words for expulsion of old highborn families back to the German swamplands: "Why should they

3 Constantin François VOLNEY, Voyage en Syrie et en Égypte, pendant les anneés 1783, 1784, \& 1785, Paris $1787,76$.

4 Henry Sumner MAINE, Village-Communities in the East and West, London 1913, 209-210.

5 Hannah ARENDTOVÁ, Původ totalitarismu I-III, Praha 2006, 250. 
(the third estate, author's comment) not drive back to the Frankish forests all those families that preserve an absurd claim to coming from the race of conquerors and to having inherited their rights? I believe that the Nation, purged in that way, would be able to become reconciled with the idea that it consists exclusively of descendants of Gauls and Romans. Actually, if insisting on distinction of our origin, should we not persuade our less lucky fellow citizens that their blood relation with the Gauls or Romans has at least equal value as that of those claiming alleged relationship with Cimbri, Welsches and other savages who had emerged from the swamplands and forests of ancient Germania?"6 In April 1793, Russian Tsarina Catherine II wrote to Melchior Grim, a German philosopher of the Enlightenment: "Do you not observe what is going on in France? The Gauls drive out the Franks. But you will see that the Franks will return, and then the raging beasts longing for human blood will either be exterminated or driven to shelters."7

In the period of Restoration, Augustin Thierry linked the narrations of the conflict of the Franks and the Gauls together with modern racial thinking and became one of the first creators of the historical idiom. ${ }^{8}$ It was not surprising that Augustin Thierry valued extraordinarily Walter Scott, appreciating highly his novel "Ivanhoe". ${ }^{9}$ Walter Scott taught him how to depict the history convincingly as conflict of antagonistic races. On 2 April 1820, Thierry published the article "Racial antipathy" ("Antipathie de race") in "Censeur européen", declaring that the Anglo-Saxon countries, Great Britain and United States of America were more lucky regions than France from the perspective of the level of achieved liberty. ${ }^{10}$ Then he turned to traditional French narration: "We believe to be only one nation, but we are actually two nations, hostile in their memories and unappeasable in their outlooks."11 France is split between successors of the defeated and descendants of the conquerors who are deaf to language of liberty and peace. Unlike Mably or Montlosier, Thierry thought that national unity of the Franks and the Gauls was impossible: "The heaven is our witness that we are not the first to recognize and declare the dark and terrible truth that the territory of France houses two hostile camps ... The history has shown very clearly that regardless of what emerged from mixture of two primitive races, their endlessly contradictory spirit has been preserved until these days in two parts of population that remained separated forever... The legitimate origin and political succession are obvious facts. Let's award them to those who claim them and let's be proud of completely different origins. We are sons of men of the third estate. This third estate has emerged from communes that were refuges of bondservants. Bondservants were those who were defeated during the invasion ..., the consequences of which must be redeemed now." ${ }^{12}$ Similarly to the Americans who got rid of the English and achieved liberty, France must be freed from the Franks. Augustin Thierry followed the pre-revolutionary Sieyès' appeal on the need to drive away the conqueror

6 Quot. Léon POLIAKOV, The Aryan Myth. A History of Racist and Nationalist Ideas in Europe, New York 1996, 28; quot. François FURET, Promýšlet Francouzskou revoluci, Brno 1994, 12.

7 Quot. POLIAKOV, 29.

8 Augustin THIERRY, Dix ans d'études historiques, Paris 1835, viii.

9 Ibidem, 133.

10 lbidem, 291-292.

11 Ibidem, 292.

12 Ivo BUDIL, Od prvotního jazyka k rase, Praha 2002, 29. 
aristocratic race back past the Rhine: "Gaul belongs to us."13 Augustin Thierry did not hide partial respect to members of Frankish aristocracy; after all, deserters from among them had helped the third estate to win the revolution and keep leading it. ${ }^{14}$ In his study "Character of the Franks, the Burgundians and the Visigoths" ("Caractère des Franks, des Burgondes et des Visigoths"), Augustin Thierry emphasized that the Franks had not been a unified nation but mere confederation and that the word "frank" did not stand for "free" but "savage" or "untamable": Young fanatics whose imagination was ignited by Odin were gathering on the other side of the Rhine to invade the Roman territory. ${ }^{15}$ Thierry's thesis that racial war and expulsion of a foreign stock could help to restore or create a free and vital national community emerged in many different variants in the course of the $19^{\text {th }}$ and $20^{\text {th }}$ Century. It achieved its most destructive shape in form of the Nazi racial totalitarianism. The July revolution of 1830 finally brought the French ("Celtic") bourgeoisie to power. ${ }^{16}$ Camille Jullian declared in 1912 in the "Collège de France": "This huge duel transformed the past of France into an unsettled and miraculous epic, comparable to battles between gods and giants lauded by Greek poets. The narration of the above mentioned epic ignited the poetic and pompous spirit of the people of the era of Romanticism. When the heat of summer 1830 faded in clear days, many people asked with enthusiasm whether the July Sun had shined on final flight of ancient conquerors and on the triumph, provided by grace of Providence, of the immortal Gallic race."17 Many German intellectuals explained the above stated symbolic degradation of Germanship in France as evidence of racial and power decline of the country. Otto von Bismarck said after the Prussian victory over France in 1871: "The 1789 revolution had brought the defeat of the German element by the Celtic element, and you can see what followed."18

In the first half of the $19^{\text {th }}$ Century, racial thinking gained much more public influence in the United States of America than in any other Western country. One French visitor to New York remarked in 1835 that every American shared two ideas: that the welfare of the country was derived from republican institutions and that Providence had awarded the world to Anglo-Saxons as fief. ${ }^{19}$ The American expansionism spreading in the population was changing its form. It was leaving the republican imperial form of the Enlightenment, inherited from the times of fight for independence and acquiring distinctive romantic and Anglo-Saxon racial character. Senator and leader of the Democratic Party Thomas Hart Benton, whose biography was written by President Theodore Roosevelt ${ }^{20}$ and who ranked among the most eloquent expansionists, spoke of arrival of members of Caucasian race to the Pacific shore as of one of the most important events in the history of mankind. In 1818 to 1819 Benton claimed already that the annexation of the Columbia River would open

\footnotetext{
13 THIERRY, 294.
}

14 lbidem, 301-311.

15 Ferdinand VALENTIN, Augustin Thierry, Paris 1895, 79.

16 BUDIL, 30.

17 Quot. BUDIL, 30.

18 Quot. BUDIL, 224.

19 Justin H. SMITH, The War with Mexico, New York 1919, 123.

20 Theodore ROOSEVELT, Life of Thomas Hart Benton, Boston and New York 1887. 
the way to trade with Eastern Asia and India to the United States and transform St. Louis into one of the greatest cities of the world. The Columbia Valley would become granary to China and Japan and asylum to emigrants from those overpopulated countries. Free republics would emerge on the Pacific shore, under the auspices of the United States. ${ }^{21}$ Mexico constituted an obstacle to the American power aspirations. The war between the United States and Mexico in 1846 to 1848 was the first international conflict interpreted as clash of antagonistic races.

Brantz Mayer, a Baltimore writer, traveller and historian presented Mexico as a laboratory of modern racial theory in the 1840s. Brantz Mayer, a half forgotten pioneer of racial thinking, viewed mixing of races as cause of economic stagnation and political collapse of the country. According to Brantz Mayer, the admixture of Arabic blood in the veins of the Mexicans had instigated their internal frictions and later the conflict with the United States of America. ${ }^{22}$ Mayer emphasized that the internal predispositions of the "Spanish race" resisted the needs and demands of modern civilization. The hatred felt by the Mexicans towards their northern neighbour resulted from their racial instinct. The Mexicans represented rather a graft of a wild Arab on a barbaric Indian than that of a highborn Spanish on a noble Aztec. The United States of America should react to such dangerous animosity, which was of other nature than the antagonism between France and England or between Genoa and Naples, by patient effort for alliance with Mexico and primarily by preventing European great powers from intervening in its internal political life. Racial merger of the inhabitants of Mexico and of the Anglo-Saxons would seal the political alliance. ${ }^{23}$

In the time when liberal nationalistic revolutions were suppressed in the European continent, Anglo-Saxon racial will and energy seemed to triumph in Northern America. It seemed to evidence that the main role in achieving collective historical greatness belongs to race and not to political institutions. From the time of the defeat of the Spanish Armada, the world was waiting for another convincing evidence of Nordic superiority. The unambiguous victory of the Anglo-Saxon United States of America over the mestizo Mexico offered it. Scottish physician and surgeon Robert Knox was an important pioneer of racial thinking of the 19 ${ }^{\text {th }}$ Century; in 1850, he published a set of his lectures called "The Races of Men: A Philosophical Enquiry into the Influence of Race over the Destinies of Nations". Knox' vision of race and racial war constituted a remarkable comment on the consequences of the Eurasian revolution, wrapped in medical idiom. According to his own statement, Robert Knox started dealing with racial issue in 1814 when he dwelt in Southern England as young military physician. ${ }^{24}$ Race became part of public discourse in the British Isles at the turn of 1840s and 1850s. Robert Knox related that fact to the 1848 events that allegedly awoke racial awareness all over Europe. Robert Knox emphasized that human nature, both individual and national, was determined by race. Since the beginning of history, mankind had been

21 Reginald HORSMAN, Race and Manifest Destiny: The Origins of American Racial Anglo-Saxonism, Cambridge 1981, 90-92.

22 Brantz MAYER, History of the War between Mexico and the United States, with a Preliminary View of its Origin, New York \& London 1848, 6

23 Brantz MAYER, Mexico; Aztec, Spanish and Republican, Hartford 1853, xv.

24 Robert KNOX, Races of Men: A Philosophical Enquiry into Influence of Race over the Destinies of Nations, London 1862, 14. 
divided into different and permanent racial types. That was the key to understanding of the past, the present and the future of mankind. ${ }^{25}$ According to Know, race was everything; science, art, civilization, everything depended on it. ${ }^{26}$ Civilization and education would not change the racial foundations of the respective population. Its religion, moral, feelings, greatness and lowness reflected the physical foundation that had not changed from the ancient times. ${ }^{27}$ Future studies of races would allow predicting future historical development resulting from mutual competition of races. ${ }^{28}$ Although the European statesmen tried to hide it, racial war was in the background of big political conflicts in Europe.

According to Robert Knox, Johann Friedrich Blumenbach and James Cowles Prichard had inadvertently converted race into an exotic, natural category, primordial element from which the modern man had liberated himself. Robert Knox emphasized that such emancipation was mere illusion. We were and would be permanently leading racial war, Robert Knox proclaimed two decades before origination of social Darwinism. ${ }^{29}$ Not in Africa or at French-Prussian border but just in the streets of London. Let's look closely at the faces of our fellow citizens and we would see representatives of different races with whom no civilization bonds could join us for good. ${ }^{30}$ Robert Knox divided Europe into three basic racial circles that should become great power complexes after strong political shakes and revolutions: the Slavs in the East, the South-German or Gothic race in the West and the Saxons or Scandinavians in the North would establish their own free republics on the ruins of the anachronistic monarchies. ${ }^{31}$ The thing that was missing, (for the time being) was the leaders. But the stability in Europe depended on its race-based political arrangement. ${ }^{32}$

Robert Knox did not believe in the future of coloured races. The Celts would subjugate many of them with sword, while the Saxons with contracts and trade. ${ }^{33}$ As for the rest, it was not sure whether they would succumb to the brutal force of the Saxons, Celts, Russians and Slavs or whether they will find protection in impenetrable forests, deserts and swamplands. ${ }^{34}$ Colourful races inhabited virtually every climatic zone; the Laplanders lived in Arctic areas, the Asians in moderate zone and the Africans in the tropics. ${ }^{35}$ The principle that power conditioned right had applied since the ancient times. On that base, the Slavic tribes had devastated Italy once, the British had seized North America and wiped out most of local population (and were later expelled by the settlers) and the Celtiberians had conquered South American. The white race asserted itself all over the planet, dominating the colourful races that were not capable of effective resistance. The Anglo-Saxons occupied

\footnotetext{
25 Ibidem, 488.

26 Ibidem, 315.

27 Ibidem, 318.

28 Ibidem, 22.

29 Ibidem, 348.

30 Ibidem, 44-45.

31 lbidem, 359.

32 Ibidem, 360-361.

33 Ibidem, 314.

34 lbidem, 218-219.

35 lbidem, 219-220.
} 
India while the Celts expanded in North Africa. ${ }^{36}$ The cold distance and indifference with which the unprecedented global aggression was performed were unheard of in human history. The natives of India were slaves, although that fact was hidden by legal fiction. Robert Knox believed that only the climatic factors unfavourable to white race had prevented Great Britain from building a "second India" in equatorial Africa. ${ }^{37}$

Racial war was a natural situation. All people believed in the race; only theorists, detached from life, denied its existence. Who cared about the Africans or barbarians? They were not of the same character as we were. They constituted obstacle and uncomfortable nuisance to be eliminated from the face of the earth. ${ }^{38}$ Saxons, as resulted from their nature, enslaved the black race, massacred the Indians and barbarians and did not recognize the Australian and Tasmanian aborigines as human beings. ${ }^{39}$ Robert Knox predicted that the Russians, after having swallowed the rests of the Mongolian empire in Central Asia and Siberia, would invade China and Japan to fight for it against the Anglo-Saxons expanding from independent Australia. ${ }^{40}$ So China and Japan would become Sarmatian or Saxon, which would put an end to the Mongolian race. ${ }^{41}$ China's weakness was noticeable. A small group of British soldiers who would not have covered more than twenty miles from the Boulogne Port towards the interior without escaping destruction humiliated an empire with three hundred million inhabitants. Instead of an alleged Chinese army numbering five million soldiers, 35 thousand armed men had gathered and immediately dispersed by European weapons. Robert Knox had the smallest illusions about China. It had not changed, unlike the West, and made no progress in the course of centuries. Its civilization was a copied imitation. The ignorance of China was equally huge as the number of its inhabitants. ${ }^{42}$ America would be Saxon, Asia undoubtedly Sarmatian, and Africa probably Celtic. ${ }^{43}$ Could Celts (i.e. the French) colonize Africa? Their last attempt (led by Napoleon) to seize Europe failed. In Algeria, they faced resistance of the determined and belligerent Arab race, much more potent than that fought by the Anglo-Saxons in India, Australia or North America. ${ }^{44}$ If the French wanted to remain in Algeria, they had to populate it. Were they able to acclimatize? According to Knox, that was the question on which not only the fate of Africa but also of Europe depended, as only successful colonization of Algeria could deter the French from a military campaign towards the Rhine. ${ }^{45}$

The frustration from unfulfilled goals of the 1848 revolution "biologized" the Western political and ideological thinking as the confidence in the potential of public space dropped. That is what enabled the war between France and Prussia, which had broken out as an

\footnotetext{
36 Ibidem, 222.

37 Ibidem, 223-224.

38 Ibidem, 268-269.

39 Ibidem, 280-281.

40 lbidem, 451.

41 Ibidem, 279-280.

42 Ibidem, 281-284.

43 Ibidem, 293.

44 lbidem, 294.

45 Ibidem, 295.
} 
actually traditional fight of two leading powers for hegemony in Europe, to be soon interpreted as fatal racial conflict between the Germans and the Celts. The race category represented a way of emphasizing the continuity of contemporary political rivalry from ancient times. Political thinking dressed itself in myth and confronted Gaul and Germania. If the Mexican-American war demonstrated unambiguously the racial superiority of the Anglo-Saxons over the Latin mestizos, the Prussian-French conflict showed the triumph of the Germanic element over the romanized descendants of the Celts in compliance with the widespread idea of racial hierarchy. The Anglo-Saxons and the Germans, two superordinate Nordic races, started controlling the world.

A day after France had declared war on Prussia on 19 July 1870, Gustave Flaubert wrote to the writer George Sand: "I am disgusted, irritated by the stupidity of my compatriots. The incurable barbarism of mankind fills me with black sorrow. ... Are we returning to racial war? There is no pretext to the terrible slaughter that is being prepared. It is craving for war's sake." 46 Then, on 3 August 1870, he added: "The racial wars may actually return. Before the century has elapsed, we will see millions of people murdering each other in one sitting. The whole Orient against the whole Europe. Why not? Great collective works, like digging the Suez Canal, may be in preparation, in one or another form, for the monstrous conflicts we even cannot imagine." 47 On Tuesday, 6 September 1870 Edmond de Goncourt met Ernest Renan at a dinner in their friends' home. Depressive mood prevailed at the table. People spoke about the great defeat, the incompetence of the government and the Prussian barbarism. The opinion sounded that the Prussian superiority resulted from mechanization of the individual, which the French were not able to achieve. Ernest Renan looked up from his plate: "In all things I have dealt with, I have always been astonished by the superiority of German intelligence and work. It is not surprising that in the skill of war, which is a lower, but nevertheless complicated art, they have achieved a superiority I could detect in all their works I have studied and I know. Yes, my sirs, the Germans are a superordinate race." 48 Hippolyte-Adolphe Taine, one of chief ideological leaders of the Third Republic, did not hide his fascination by the Germanic nature either: "It is a race that comes as the last, bringing new civilization, endowed with new character and spirit, to the world in times of decadence of its Greek and Latin sisters... It was controlled by moral and manly instincts, including excellent sense of independence, liking for serious and strict habits, feelings of loyalty and respect, cult of heroism. These are qualities of a late, but more healthy civilization that is less endowed with moral freedom and elegance but much more based on truth and justice." 49 Heinrich von Treitschke, a historian, stated in his essay in September 1870: "The subordination of the German race to France has never been healthy. Vassalage of free people towards half-educated barbarians offends the sense of history." 50

The Paris Anthropological Society restored its regular sessions on 6 July 1871. On 21 September 1871 already, Armand de Bréau de Quatrefages presented his paper "Prussian

46 Gustave FLAUBERT, Korespondence, Praha 1930, 195-196.

47 Ibidem, 196.

48 Edmond de GONCOURT, Journal des Goncourt, Premier volume, 1870-1871, Paris 1890, $25-26$.

49 Hippolyte-Adolphe TAINE, Histoire de la littérature anglaise, Paris 1905, 63.

50 Geoffrey WAWRO, The Franco-Prussian War: The German Conquest of France in 1870-1871, Cambridge 2003, 334. 
race" ("La race prussienne") there, as the probably most acute anthropological reaction to the Prussian-French War. ${ }^{51}$ Quatrefages declared at the beginning that he had always opposed application of anthropology on political life. He said that, as the differences between the white and black races or the chasm gaping between the English and the Indians in spite of long lasting colonial coexistence evidenced, the race was source of feeling of mutual alienation and different identity. But that fact could not be applied in Europe, as racially pure types could be found only with difficulty among its population. What was the foundation of the dangerousness of anthropological knowledge to world peace? Its ability to "eternalize" war, to make it an unchangeable part of human existence. If hostility emerged between nations or states, intolerance could be mitigated by the spirit of chivalry and mutual respect and the antagonism would not exceed a degree that would thwart conciliation and permanent peace. Nothing of that applied to the concept of race that included something primordial, animal and fatal. Two populations identified with different races led fanatic fight for mere survival, ending by total extermination of one of them. The stubborn and insatiable hatred resulting from different racial identity was limitless. The history had illustratively shown what racial war meant. ${ }^{52}$

In 1871, Charles Darwin wrote in "The Descent of Man": "With savages, the weak in body or mind are soon eliminated; and those that survive commonly exhibit a vigorous state of health. We civilised men, on the other hand, do our utmost to check the process of elimination; we build asylums for the imbecile, the maimed, and the sick; we institute poorlaws; and our medical men exert their utmost skill to save the life of every one to the last moment. There is reason to believe that vaccination has preserved thousands, who from a weak constitution would formerly have succumbed to small-pox. Thus the weak members of civilised societies propagate their kind. No one who has attended to the breeding of domestic animals will doubt that this must be highly injurious to the race of man. It is surprising how soon a want of care, or care wrongly directed, leads to the degeneration of a domestic race - but the exception in the case of man himself - hardly any one is so ignorant as to allow his worst animals to breed." 53 Elsewhere in his popular book, Charles Darwin mentioned: "Now let us apply these generally-admitted principles (of natural selection, author's comment) to the races of man, viewing him in the same spirit as a naturalist would any other animal." ${ }^{54}$ Charles Darwin did not hesitate to consider the application of the laws of natural selection, he had been one of the first to describe, on human society.

The authors classified more or less justifiably among representatives of social Darwinism believed that Darwin's theses could be applied on human society and that harmonization of natural and social system through Darwinism would allow either understanding changing the society, or changing it radically, i.e. reforming and revitalizing it positively, even at the cost of lamentable, but necessary elimination of the weak, the disabled and the inferior.

51 Francis SCHILLER, Paul Broca: Founder of French Anthropology, Explorer of the Brain, Berkeley 1979, 238. The whole study La race prussienne was published in La Revue des Deux Mondes, on 15 February 1871, 648-669.

52 Armand de Bréau de QUATREFAGES, La race prussienne, in: Bulletins de la Société d'Anthropologie de Paris, 4, 1871, 183.

53 Charles DARWIN, O původu člověka, Praha 1970, 93 (The descent of man, London, John Murray, Volume 1, 1 st edition, http://darwin-online.org.uk/content/frameset?itemID=F937.1\&viewtype=text\&pageseq=1).

54 Ibidem, 116. 
Social Darwinism opened way not only to justification of domination of so called lower, inferior non-European races but also of eugenic programs of racial refinement within the Western civilization. André Pichot emphasized that the idea of stubborn and protracted fight of "progressive" Darwinism against "reactionary" creationism was a popular myth. ${ }^{55}$ In reality, Darwinism had spread among Western intellectuals relatively quickly, as it was forthcoming to the reformist, secular, progressive, but also militant and nationalist spirit of the age. ${ }^{56}$ Leading personalities of the scientific, political and cultural life of that time in Great Britain, the United States, France and Germany claimed allegiance to it.

The problem of Darwinism and Charles Darwin himself consisted in frequent tendency to use figurative language that was often interpreted out of control and intention of the original creators. Social Darwinism and its lamentable ideological and political consequences emerged usually in consequence of the above mentioned semantic shifts. Only the origin of so called synthetic theory of evolution in 1936 to 1947, in which researchers like Theodosius Dobzhansky, Julian Huxley or Ernst Mayr connected Darwinism with Mendel's laws of heredity, brought terminological specification that prevented further false and violent analogies. The ideological conflicts provoked by the phenomenon of social Darwinism and its diverse derivatives have been burdening coexistence of social and natural sciences, as for example the disputations concerning sociobiology and evolutionary psychology have shown.

Soon there were critics imputing the worst intentions to Darwin's followers. Jacques Novicow wrote in early $20^{\text {th }}$ Century already that social Darwinism had enabled raising rules of banditism to the level of universal natural laws. ${ }^{57}$ It is nevertheless true that racial ideology, including anti-Semitism, had acquired official acknowledgement thanks to social Darwinism, enjoyed popularity among wide public and started being applied in legislation. Frederick Pollock, a renowned lawyer and historian, expressed in his letter to Edward August Freeman from 26 August 1876 the motto of the ideology in which Aryanism and Darwinism constituted a consistent unit already: "As an Aryan and Darwinian, I can see no reason for preserving inferior and savage races except that the superior ones get demoralized in the process of supplanting them if it is done by violence - and especially when the irreclaimable barbarian has got edged tools in his hands. Turks with Krupp guns and paper money are a monstrosity. "58

Clémence-Auguste Royer, a French writer, formulated, in the preface to her own translation of Darwin's "On the Origin of Species" into French from 1862, theses that constituted the theoretical foundation to social Darwinism. In the study "The Origin of Man and Societies" ("Origine de l'homme et des sociétés", 1870), Royer joined the Darwinist interpretation of human evolution with the concept of racial hierarchy. She did not believe that the Australian aborigines, Indians, Arabs and Chinese were able to get over the development stage in which they found themselves. Only the European branch of the Aryan family was able

55 André PICHOT, La Société Pure: De Darwin à Hitler, Paris 2000, 75.

56 Celestin BOUGLÉ, La démocratie devant la science: Études critiques sur l'hérédité, la concurrence et la différenciation, Paris 1904.

57 Jacques NOVICOW, La Critique du darwinisme social, Paris 1910, 139, 142.

58 C. J. W. PARKER, The Failure of Liberal Racialism: The Racial Ideas of E. A. Freeman, in: The Historical Journal $24,1981,4,835$ 
to do that. ${ }^{59}$ The Aryan represented the top of evolution of mankind. ${ }^{60}$ The warrior and conqueror instinct, natural human equipment, helped the progress of humanity, according to Royer. Without it, the racially superior Aryan pastoral people would not have subjugated the Dravidian population and conquered other parts of the world in which later great civilizations blossomed. ${ }^{61}$ The above mentioned civilization mission continued in modern colonialism that, nevertheless, should not result in mixing of races, considered immoral by Royer. ${ }^{62}$ She doubted that racially mixed populations were able to create stable political structures. ${ }^{63}$ In relation to "lower" races, any sentimentalism and false humanism should be eliminated. Those races were trapped in primitive and animal timelessness from which we were not able to free them. They constituted human fossil relics without hope and future. ${ }^{64}$ Clémence-Auguste Royer highlighted the existence of the caste system of the archaic Aryans whose warrior caste had constituted the most efficient tool of expansion. The Roman Empire had been defeated just because it had eliminated that institution, while the barbarian Germans had preserved it. If the French Revolution was to be a real historical landmark in the history of mankind, then cancellation of feudal privileges of 4 August 1789 was to represent only elimination of anachronistic and parasitizing aristocracy that had not fulfilled its role any more. At the same time, space was to be opened for the rise of the new warrior and conqueror caste, a real regenerated aristocracy embodying the Aryan virtues. The alternative to which Rousseau and Proudhon called, a homogeneous mass of equal citizens, constituted a way to social collapse. ${ }^{65}$

Race, racial war, racial ideology as tool of national revitalization and eschatology of ethnic homogeneity ${ }^{66}$ constituted explicit terms or implicit concepts that found convenient environment in the intellectual and political climate of the 'fin de siècle'. The term of racial war, once propagated by Robert Knox, became a common part of the vocabulary of intellectuals. In Germany, it was used not only by the leader of Pangerman League, Heinrich Class, but also by Chancellor Theobald von Bethmann-Hollweg. ${ }^{67}$ Élie Halévy, Anglophile, Protestant and confirmed republican, remarked after the battle of the Marne that the conflict had acquired the character of total racial war. ${ }^{68}$ So Mirabeau's prediction from the French Constituent Assembly that for wars of "free nations" we will regrets wars of kings came true. ${ }^{69}$ At the turn of the nineteenth and twentieth centuries, the semantic differences between ethnicity and race almost disappeared. Race acquired so to say magical force in the imagination of the inhabitants of the West of that time, swallowing the traditional territorial

59 Clémence-Auguste ROYER, Origine de I'Homme et des Sociétés, Paris 1870, 77.

60 lbidem, 99-100.

61 Ibidem, 533-534.

62 Ibidem, 532

63 Ibidem, 498-499, 536-537.

64 Ibidem, 221-224.

65 Ibidem, 567-577.

66 Shelley BARANOWSKI, Nazi Empire: German Colonialism and Imperialism from Bismarck to Hitler, Cambridge 2011,6 .

67 Ibidem, 65-71.

68 François FURET, Le passé d'une illusion. Essai sur l'idée communiste au XXe siècle, Paris 1995, 66.

69 Julien BENDA, Zrada vzdělanců, Praha 1929, 24. 
language or blood patriotism. People were ready to identify themselves with the Aryans, Anglo-Saxons, Teutons, Germans, Celts, Gauls or Slavs although having only vague notion of the origin of those terms. As for example Leon Dominian or William Zebina Ripley emphasized, the borders of national states and racial groups did not overlap. Northern France was probably more Teutonic than Southern Germany; Eastern Germany more Slavic than Russia. We can find typically Nordic types in Germany relatively seldom out of the Hannover region, and there are undoubtedly more of them in Northern France than in Bavaria. ${ }^{70}$ The metaphorically mentioned words (Celtism in France, Teutonism in Germany and Anglo-Saxonism in Great Britain) reflected collective national aspirations. Popular authors like Charles Dilke in his book "Greater Britain", 1869, or John Seeley in "The Expansion of England", 1882 showed the British Empire as a work of the Anglo-Saxons, the chosen and superior race. George Frederick Samuel Robinson, Lord Ripon, emphasized the racial qualities of the Anglo-Saxons in his speech held in the House of Lords in 1908.

The tragedy of modern age consisted, according to Georges Vacher de Lapouge, French social Darwinist and founder of anthroposociology, in prevalence of social selection over natural selection, which had caused spreading of lower brachycranial (broad-headed) populations, marginalization of superior dolichocranial (long-headed) races and subsequent degeneration of the Western society. In France, unfortunately, the dominance of the dolichocranial individuals had been weakened by the French Revolution, allowing the brachycranial representatives of the third estate to control the country. Therefore France could not stand the German energy and either had to unite with that country or become a satellite of the stronger power. The economic rise of Germany was undoubtedly impressive, and some parts of Austria-Hungary, primarily the Czech Countries, would probably become part of the German Empire. But Germany served only as bumper against the expansion of the Russian Empire. The Russian expansion could be slowed down by Anglo-Saxon states, but Russia would expand to the Atlantic and to the Mediterranean. ${ }^{71}$ Russia, with prevalence of Aryan population, would dominate China and India and become lord of the world in the foreseeable future. ${ }^{72}$ The only power that could prevent it was United States of America. ${ }^{73}$ In 1887, Georges Vacher de Lapouge predicted: "Conflict of races is going to break out inside nations and among nations just now, and nothing remains but to ask whether the ideas of brotherhood and equality of people are not contrary to nature. I am convinced that in next century, people will kill each other by millions because of difference of one or two degrees of cranial index. People will be identified through that index that has substituted the biblical shibboleth and the linguistic bond, and the last sentimentalists will witness huge mass extermination." 74

War and race constituted the two main components of the Nazi worldview. Konrad Heiden means that Adolf Hitler's actual goal was not Germany but unification of the Aryans and

70 Frank H. HANKINS, The Racial Basis of Civilization, New York \& London 1926, 9.

71 Georges VACHER DE LAPOUGE, L'Aryen, son role social, Paris 1899, 494-495.

72 lbidem, 332.

73 Jean COLOMBAT, La Fin du monde civilisé, Paris 1946, 124.

74 Quot. BUDIL 2002, 213; quot. PICHOT, 60. 
anti-Semites in order to achieve world dominion, ${ }^{75}$ predicted by Houston Stewart Chamberlain. In Hitler's speeches and dreams of the "millennial empire", we can feel remote echo of the "great geopolitical turn" from the period of 1756 to 1815 when the balance of powers among traditional Eurasian great powers was disturbed. Global fight for hegemony set in, and Great Britain emerged as its winner. That empire presented itself externally as a "moral empire" with a special "civilization mission" based on liberal and late-enlightenment values. But we should not forget the relatively complicated ethnic development of the British Isles where, in the $5^{\text {th }}$ and $6^{\text {th }}$ Centuries, the Celtic element clashed with the Anglo-Saxon and later with the Norman element. The above mentioned fight, including colonization of Ireland and violent subjugation of Wales and Scotland, was presented at the turn of the $18^{\text {th }}$ and $19^{\text {th }}$ Centuries by romantic writers and historians as racial conflict concluded by triumph of the Anglo-Saxon race that had assumed control of the world. That demonstrated seemingly illustratively that the way to build an empire led through purity of race getting rid of "inferior" elements. Social Darwinists suggested that racial revitalization could be performed outside a lengthy historical process, through rational reforms and tools of modern science freed from hindering moral "prejudices" and sentiments. Adolf Hitler, admirer of the Anglo-Saxons, imitated the British example in the spirit of genocidal amorality of social Darwinism in political and ethnic conditions of Central European space. Central Europe, unlike the British Isles, was inhabited, side by side with the Germans, not by Celts but by Jews and Slavs. The German empire could emerge only by their elimination in Hitler's visions. The escape to the dreamlike and unreal world of "racially pure community" resulted at practical level in the logic of systematic racial genocide and incompetence of pragmatic foreign policy that would have chance of success. Germany led by Nazis was not able to make use even of the relatively favourable geopolitical situation to achieve relatively lasting dominance over Europe. Imagination opposed concrete claims and demands of reality.

The romantic colour of race faded in Auschwitz, losing historical attractiveness. The world of early $21^{\text {st }}$ Century resembles, in many respects, the period before 1914, characterized by fully open ethnic, religious and racial animosity, than the epoch between capture of Berlin and the fall of the Berlin Wall, when people, in principle, fought for the legacy and interpretation of the ideals of French Revolution. The transcendent Robespierre's vision of the Supreme Being and the chthonic mythology of the Aryan represent two archetypal personifications between which the main ideological and political passions of two centuries took place from 1789 to 1989.

\section{Abstract}

The concept of race and the phenomenon of racial ideology, strengthened by social Darwinism, led to substantial reassessment of traditional concept of war as historical phenomenon in the second half of the $19^{\text {th }}$ Century. An aberration, morally problematic activity that can be resorted to only under exceptional and morally justifiable circumstances, became a vital principle and integral part of human existence. Not "eternal peace" but permanent 
"struggle for survival" was to constitute the desirable historical aspiration. That fact influenced markedly the character and course of World War I and principally of World War II. In the following study, I will try to show that the intellectual and cultural environment that allowed origination and expansion of racial thinking and the concept of racial war reflected, to considerable extent, the specific geographical-political situation of the $19^{\text {th }}$ Century. The racial imagination constituted symbolical comment and legitimization strategy of redistribution of global powers in favour of the West.

\section{Keywords}

war, race, racial ideology, social Darwinism, Eurasian revolution, symbolic imagination, colonialism

\section{References}

ARENDTOVÁ, Hannah: Původ totalitarismu I-III, Praha 2006.

BARANOWSKI, Shelley: Nazi Empire: German Colonialism and Imperialism from Bismarck to Hitler, Cambridge 2011.

BENDA, Julien: Zrada vzdělanců, Praha 1929.

BOUGLÉ, Celestin: La démocratie devant la science: Études critiques sur l'hérédité, la concurrence et la différenciation, Paris 1904.

BUDIL, Ivo: Od prvotního jazyka k rase, Praha 2002.

COLOMBAT, Jean: La Fin du monde civilisé, Paris 1946.

DARWIN, Charles: O pưvodu člověka, Praha 1970.

DARWIN, John: After Tamerlane: The Global History of Empire since 1405, London 2007.

FLAUBERT, Gustave: Korespondence, Praha 1930.

FURET, François: Promýšlet Francouzskou revoluci, Brno 1994.

FURET, François: Le passé d'une illusion. Essai sur l'idée communiste au XXe siècle, Paris 1995.

GONCOURT, Edmond de: Journal des Goncourt, Premier volume, 1870-1871, Paris 1890.

HANKINS, Frank H.: The Racial Basis of Civilization, New York \& London 1926.

HEIDEN, Konrad: Der Führer - Hitler's Rise to Power, Boston 1944.

HORSMAN, Reginald: Race and Manifest Destiny: The Origins of American Racial Anglo-Saxonism, Cambridge 1981.

KENNEDY, Paul: Vzestup a pád velmocí: Ekonomické proměny a vojenské konflikty v letech 1500 až 2000, Praha 1996.

KNOX, Robert: Races of Men: A Philosophical Enquiry into Influence of Race over the Destinies of Nations, London 1862.

MAINE, Henry Sumner: Village-Communities in the East and West, London 1913.

MAYER, Brantz: History of the War between Mexico and the United States, with a Preliminary View of its Origin, New York \& London 1848.

MAYER, Brantz: Mexico; Aztec, Spanish and Republican, Hartford 1853.

NOVICOW, Jacques: La Critique du darwinisme social, Paris 1910.

PARKER, C. J. W.: The Failure of Liberal Racialism: The Racial Ideas of E. A. Freeman, 
in: The Historical Journal, 24, 1981, 4, 825-846.

PICHOT, André: La Société Pure: De Darwin à Hitler, Paris 2000.

POLIAKOV, Léon: The Aryan Myth. A History of Racist and Nationalist Ideas in Europe, New York 1996.

QUATREFAGES, Armand de Bréau de: La race prussienne, in: Bulletins de la Société d'Anthropologie de Paris, 4, 1871, 182-185.

ROOSEVELT, Theodore: Life of Thomas Hart Benton, Boston and New York 1887.

ROYER, Clémence-Auguste: Origine de l'Homme et des Sociétés, Paris 1870.

SCHILLER, Francis: Paul Broca: Founder of French Anthropology, Explorer of the Brain, Berkeley 1979.

SMITH, Justin H.: The War with Mexico, New York 1919.

TAINE, Hippolyte-Adolphe: Histoire de la littérature anglaise, Paris 1905.

THIERRY, Augustin: Dix ans d'études historiques, Paris 1835.

VACHER DE LAPOUGE, Georges: L'Aryen, son role social, Paris 1899.

VALENTIN, Ferdinand: Augustin Thierry, Paris 1895.

VOLNEY, Constantin François: Voyage en Syrie et en Égypte, pendant les anneés 1783, 1784 \& 1785, Paris 1787.

WAWRO, Geoffrey: The Franco-Prussian War: The German Conquest of France in 1870-1871, Cambridge 2003. 